$£ 1,000$ million or thereabouts. (Boeing's past successes may owe something to its economical ways of working.) Even allowing for the technical sophistication of the new machines and their power plants, and for the value of the potential prizes to be won, it is hard to see how costs on this scale can be justified. Part of the explanation is the ambition of most manufacturers to keep in being the small armies of skilled people which constitute their design teams. It would do no harm, and indeed might even benefit the aircraft industry itself, if the wisdom of these practices were closely examined by people skilled at telling not merely whether carbon-fibre composites are better for some technical purpose than the new aluminium-lithium alloys, but whether the processes of design and development need be as expensive as they have become. The economic benefits could be substantial - more flexibility in too tightly hierarchical an industry, easier access by the people to a technology whose benefits are already great, but which could be huge. Governments will not attempt the hard-eyed scrutiny that the aircraft industry needs, but would undoubtedly welcome the results. The responsibility falls squarely on the technical community. Why not (for Britain) Farnborough?

\section{Too brief encounter}

\section{The likely outcome of the space weapons talks is that the negotiators will meet only to adjourn.}

THOSE who believe diplomacy a dull business should think again. Some weeks ago, the Soviet Union invited - some would say challenged - the United States to a conference at Vienna on the use of the space above the atmosphere for the siting of military weapons. The date suggested for the opening of the conference is 18 September, less than two weeks from now. Yet as things were earlier this week, nobody knew for certain whether two small armies of diplomats would actually arrive, ready to begin talking to each other. Careful people that they are, the potential members of the negotiating teams have arranged for hotel rooms to be booked on their behalf.

But Mr Konstantin Chernenko is clearly a little anxious that nothing at all will happen. In his interview with Pravda published at the weekend, he made noises apparently designed to soften the quarrel there has been with the United States about the agenda for the talks. If, he suggested, the United States would agree to talk about space weapons only at Vienna, he might ensure that there would be negotiations at another place and time about the issues the United States says it must discuss - the disposal of nuclear weapons in Europe and more broadly. Unfortunately, $\mathrm{Mr}$ Chernenko seems to have reckoned without the American calendar, temporal and electoral. Last weekend was Labor Day weekend, when citizens of the United States do not labour. And with President Ronald Reagan off to a good start in his campaign for re-election only two months from now, giving hostages to fortune in a negotiation that could not be complete before election day was bound to go against the electoral grain. So the State Department quickly announced that there was nothing new in what Mr Chernenko had to say, even though it is clear that it provided an opportunity that could have been exploited if anybody had felt so inclined.

What happens next? The most serious danger is that the preoccupation of even enlightened spirits in the United States with the election will blind one partner in the talks to the importance of what needs doing. Meanwhile, even the President and his advisers might prudently calculate (as they should have done during the last election campaign) that talks with the Soviet Union will be necessary once the dust has settled. Just as well to get something started before the election, but not to get too deeply embroiled in negotiations until the polls have taken place. So the likely calculation, at the State Department, is to aim at a preliminary encounter over space weapons, a polite statement of the need to talk about other things as well and an of fer to adjourn the impending negotiation until something can be arranged. Whether $\mathrm{Mr}$ Chernenko and his colleagues will agree is entirely unclear.

\section{Academic divisions} Polytechnics should be made into universities or otherwise transformed.

THESE are busy but depressing days for polytechnics, the Cinderellas of the British system of higher education. For this is the season of the year at which would-be students denied places at universities turn to the polytechnics in the hope of being fitted in. On past form (and the figures released earlier this week by the Universities' Central Council on Admissions), something like 100,000 applicants for university places will be refused (but 75,000 will be accepted). Those turning to the polytechnics for an undergraduate education will; however, be douched with cold water by the report now published of a study of Expectations of Higher Education commissioned in 1980 by the Department of Education and Science and carried out by the Department of Government at Brunel University, the head of which (Professor Maurice Kogan) is as much an educationalist as anything else. The short message of a formless document is simple - employers are biased against the recruitment of graduates from the polytechnics, preferring the products they are used to graduates from universities and especially from Oxford and Cambridge. This unsurprising news will be a slap in the face for many of the young hopefuls now hurrying off to the public sector in the hope of finding places as undergraduates. For those concerned with the future of British higher education, however, it should be a reminder that present arrangements are far from being sensible, and should urgently be scrapped.

Britain is not unique among industrialized nations in maintaining two kinds of institutions of higher education. Usually there are more vocational educational institutions. The distinctiveness of the British system is that the polytechnics were established overtly as an alternative to the university system, and have ever since been advertised as such. Whether the motives of the minister responsible, the late Mr Anthony Crosland, were political (British universities were already becoming unpopular with politicians), economic (the technical colleges from which the polytechnics emerged were thought to be cheaper) or pragmatic (what else could have so quickly increased the supply of graduates?), the designation of 26 polytechnics as graduating institutions within what is called the binary system turns out to have been a mistake. If there are two classes of institutions, one of which is seen to attract less highly qualified students (and probably less talented teachers), yet which has failed in nearly twenty years to make a characteristic mark, who can be surprised if that one continues to seem second-rate?

The prejudice of employers of all kinds against polytechnic graduates is understandable, even forgivable, on the basis of the data collected by the Kogan study. The school-leaving qualifications of polytechnic students, which span a spectrum overlapping with that of university entrants, are in general and on the average lower than those of new university undergraduates. While any process of education must somehow be capable of improving on people's attainment at the outset of their academic careers, nobody should be surprised that some of these measurable characteristics persist - and that when jobs are hard to find, employers take the easy way out. But all this is unfair to the polytechnics, many of which are in every way at least as competent as fully-fledged universities, and as successful in preparing their students for valuable careers. Especially because of the way that, in Britain, the sharpness of the binary division is accentuated by the academic snobbery which is rife, there is the strongest possible reason for its abolition. The sensible course would be to set a term, say five years from now, when all these institutions would be freed from the apron-strings of the local authorities that now watch over them, some to become rounded institutions of higher education, others to make their way in the world in different ways, perhaps by providing the distinctively vocational higher education that was originally, and inconsistently, part of the reason for their creation. Others might have to sink without trace. 